\title{
Research on the Evaluation Index System for Patent Financing Capacity of High-tech Enterprises
}

\author{
Zhao-Hui Chen* \\ School of Management \\ Guangxi University of Science and Technology \\ LiuZhou, P. R. China \\ chance168@163.com
}

\author{
Zhi-Juan Zhou \\ School of Management \\ Guangxi University of Science and Technology \\ LiuZhou, P. R. China \\ 1574438724@qq.com
}

\begin{abstract}
High-tech enterprises have been playing important role in $R \& D$ and patent commercialization, yet the process often face capital bottlenecks. Under these circumstances, this paper proposes an index system for evaluating the patent financing capacity of enterprises from the perspective of the combination of patents and financing. This paper combed the related literatures, defined the connotation of patent financing capability and analyzing the dilemma of patent financing of high-tech enterprises with inductively summarized research methods, analyzed the factors of patent financing capacity from three dimensions of patent value, business status and external financing environment. Finally, the high-tech enterprise patent financing capability evaluation index system which consists of 9 secondary indicators and 27 third-level indicators has been constructed. The system helps to measure the financing capacity and reveal the key elements which enhance financing capabilities, and then promotes the process of patent commercialization in high-tech enterprises.
\end{abstract}

Keywords_Patent financing capacity; Patent value assessment; Evaluation index system

\section{INTRODUCTION}

Technological innovation has been at the heart of global economic recently. With the more accumulation of intellectual property rights such as patents, the more important role the high-tech enterprises are playing in R\&D and transformation of invention. Yet the realization of innovative performance is often deeply constrained by funds shortage in the process above. So, to get adequate sources of funds, it is not only required for the companies to sell their product in market but also to own the financing capabilities. The effective use of intangible assets such as patents, which increases the financing channels and enhances the financing capability in order to add the financing value of these assets, is now an important problem to resolve.

Patent rights can bring monopoly profits to enterprises in the context of their continuing operation. But the enterprises have to solve the shortage of funds in production and operation process. The definition of patent financing capacity in this paper is that the ability of attracting a certain amount of funds by some specific ways of using patents. These main ways of patent financing include licensing, transfer, pledge, securitization, and venture capital.

This paper is supported by two fund projects: the National Natural Science Foundation of China (Grant No. 71864005), Guang xi University of Science and Technology Postgraduate Research Innovation Project(Grant No. GKYC201805)

\section{THE MAIN DIFFICULTIES OF PATENT FINANCING}

\section{A. Difficult to evaluate patent value}

The value of patents is generally reflected in social value and economic value. The former is social value which use the granted patent to promote social development and progress, and the latter is economic value which brought by the patent owner's benefit from patented technology. In western economics, price is a reflection of the value, so patent value can be measured by future cash flow gains. However, in terms of patent value assessment, China's assessment agencies lack unified legal regulations, generally small scale, unbalanced layout, non-standard operations, and weak integrated service capabilities. Yet at present, there is still no recognized and effective method for evaluating patent value. The subjective awareness of evaluators often plays a leading role, leading to a large gap in valuation prices from different agencies[1]. Therefore, when a lending institution issues patent loan, the loan amount is far lower than the patent evaluation value, that is lower than the patent value.

\section{B. High cost of patent financing}

High-tech enterprises are different from ordinary enterprises in which they have fast technology replacement and low rate of conversion of technological inventions. They are characterized by high risk, high investment, and low fixed assets. Funding needs of such companies mainly focus on the initial period and expansion period[2]. In the initial stage, firstly, the company's own operating scale, profitability at a disadvantage. Secondly, the initial investment is high, the capital demand is large, and the financing channels are very narrow. Third one is, sources of funding rely mainly on government financial subsidies, but the support is limited. Fourthly, there are few fixed assets and there is no guarantee. In the expansion phase, enterprises have no government financial funds to support, and the funding needs are even greater. Based on these characteristics of enterprises above, lending institutions will set high thresholds, so that increase corporate financing costs.

\section{Few patent financing channels}

In western countries, patent financing models generally include patent trust, patent securitization, pledge of patent guarantee, and patented technology, etc. However, there are only two modes of patent pledge financing and patented technology in China. The former belongs to debt financing and the latter belongs to equity financing. In particular, government 
subsidy financing also belongs to a type of financing channel for enterprises. It is a kind of debt financing with a low interest rate and it has a policy tendency. The central or local government only provides corresponding government support for certain special industries or enterprises and innovative projects[3]. Debt financing costs are paid interest and financial expenses and there are tax-deductible in tax law. Debt financing generally requires companies to show excellent business performance. Equity financing costs are low, and there is no tax-deficit effect in the tax law, which increases the cost of taxation. In the bankruptcy liquidation, the creditor is given priority to be paid to the shareholders, and the shareholders' equity may be damaged at this time. Therefore, regardless of debt financing or equity financing, there is a certain degree of financing difficulty for enterprises.

\section{RESEARCH ON INFLUENCING FACTORS OF PATENT FINANCING CAPACITY}

\section{A. Business status and Patent value}

Yao Wangxin found that the initial financing capacity of intellectual property rights was mainly influenced by two major types of factors: intellectual property valuation and intellectual property financing. And using factor analysis methods for screening and classification, a total of 6 categories of 37 factors affecting the financing capacity of intellectual property[4]. Among them, the company's operating ability and company's management ability belong to the business status of the company. The other 4 types of factors reflect the value of the company's intellectual property from its own characteristics and market characteristics. Xue Zhili analyzed the status of the financing of intellectual property in practice, and proposed 9 types of intellectual property financing impact factors, of which the operating factors and management factors belong to the business status of the company, the remaining 7 factors can also reflect the value of the company's intellectual property[5]. Kuo Caolin et al. believe that the most direct factor affecting financing capacity is the ownership characteristics of intellectual property such as reproducibility, legality and exclusivity, even affect the transfer, disposal and other issues, and the expected future cash flow is the primary factor in financing constraints. The better the company is in operating, the better it is to obtain stable cash flow, the lower the financing risk the company will bear, the brighter the technology prospect in the market, and the easier it is to win financing support and trust[6]. Zhu Sha selected 204 patent pledge contracts as a sample and empirically analyzed the impact of patent value, corporate information, and pledged financing environment on the amount of patent pledges[7]. Zhang Hongfang, standing on the perspective of a patent right-making enterprise, analyzed the characteristics of patents in the patent right pledge and the characteristics of the company's business management, constructed the patent pledge enterprise index system. And also proposed the patent feature index as a reference for financial institutions to carry out the patent right pledge business, used to analyze the property and value of the patent right pledge[8]. In summary, the characteristics of business status and the value of patents have a significant impact on patent financing capacity.

\section{B. External financing environment}

Kuokaoulin et al. also mentioned that the lower the transaction cost, the more perfect the credit evaluation system, the more professional and authoritative the evaluation agency, and the stronger the guarantee ability, so the stronger the debt financing capacity of intellectual property rights. Hua Hefeng et al. constructed an evaluation index system for intellectual property financing capacity of technological small enterprises, considered that external market environment factors include government support policies, regional financial environment, industry development speed, and non-financial intermediary services[9].

In the real world, financial institutions are most concerned about the issue of patent loan to high-tech companies that own core competitiveness of the company-patented technology or non-proprietary technology. The financial institutions firstly pay attention to the value of patents that the benefits from patents are expected to bring to the owners or the users in the real market. And secondly, the financial institutions pay attention to the company's operating conditions, development level. Only if the company continues to operate effectively, can patents play a greater role. Of course, financial institutions issuing loans will not ignore the government's policy orientation, and the related policies will also be included in their consideration.

Therefore, the authors state that the patent value, business status, and external financing environment are the three dimensions affecting the patent financing capacity and can be the basis for the design of the evaluation index system for patent financing capacity.

\section{EVALUATION INDEX SELECTION AND SYSTEM CONSTRUCTION}

\section{A. Indicator selection for measuring patent value}

Huang Qing et al. constructed a set of patent evaluation system from the three aspects of patent quantity, quality and value. The quantitative indicators, quality indicators, and value indicators can separately represent the market's emphasis on patents, technological innovation, and the role of patents in market economic activities[10]. Wan Xiaoli and Zhu Xuezhong, based on the dynamic value of patents, proposed the measurement of patent value from three aspects: technical value, market value, and value of rights[11]. Liu Shuai constructed a patent value evaluation index system for different industries from three aspects: legal characteristics, technical characteristics, and economic characteristics[12]. Lv Xiaorong and $\mathrm{Gu} \mathrm{Li}$ et al proposed that patent technology value reflect the inherent quality value of patents[13]. Hu Sin selected four indicators to analyze the comprehensive index of patent quality, which is the proportion of effective invention patents, the number of patents of the same family, the proportion of patents maintained for more than 10 years, and the number of times the patents citation[14]. Zhang Xiaoyue studied the evaluation index of patent quality by way of the perspective of business performance, and measured the quality of patents from two dimensions, namely, patent citation index and patent retention period[15]. 
Based on the existing evaluation index of patent value and the characteristics of high-tech enterprises, this paper evaluates the value of patents from three aspects: patent technical characteristics, legal characteristics, and market characteristics. The characterization of patent technology refers to the quality of patents. The number of effective invention patents, the number of patents of the same family, and the duration of patent retention are used to measure the characteristics of patent technology. The characteristics of the patent market reflect the degree of performance of patented technology or patented products in the trading market, which are measured by the market demand for patent technology, the degree of substitutability of patented technology, the degree of competition in the market for patented products, and the remaining economic life. In terms of patent legal characteristics, the remaining validity period of patents, the number of patent licenses, the number of patent infringement lawsuits, and the number of patent invalid lawsuits are selected to reflect the degree of stability of patent rights.

\section{B. Indicator selection to measure business status}

Enterprises applying for patent pledge loan need to provide the company's balance sheet for the previous three years up to the assessment date, audit reports issued by certified public accountants, patent certificates, relevant information on patents, and basic information of the company. The bank audits the information submitted by the company and comprehensively analyzes the company's profitability, debt repayment ability, and operating ability according to the financial data provided by the company to examine the loan risk.

$\mathrm{Xu}$ Wei analyzed theoretically the influencing factors of corporate finance capabilities, and established the SME financing capacity index system from the five dimensions of growth ability, profitability, management ability, support ability, and innovation ability[16]. Wu Xiaolin analyzed the influencing factors of the financing capacity of high-tech companies, the research showed that the scale of the enterprise had the most significant impact on the financing capacity of the enterprise[17]. Zhang Haohao believes that profitability is an important indicator of the efficiency of enterprises and reflects the ability of enterprises to obtain profits. The stronger the profitability, the more cash flow the company has and the more reliable the guarantee of debt repayment. Therefore, the strength of profitability is directly related to the size of the company's solvency[18]. Xu Shiying pointed out that operational capability is the utilization efficiency of various assets of enterprises, reflecting the efficiency of enterprise asset operations, emphasizing the asset turnover of enterprises and the management level of assets. Generally, having strong operational capability indicates that the company has strong survivability[19].

Under normal circumstances, the analysis of financial statement indicators, such as the scale of the company, profitability, debt repayment ability, growth ability, operational ability and other indicators, can be comprehensive evaluation of the overall operation of the company[20,21]. High-tech enterprises belong to knowledge-intensive enterprises, so they use firm funds to measure the scale of the enterprise. Profitability measures the ability of a company to obtain profits, select three indicators such as sales net profit, sales gross margin, and return on equity. Repayment ability reflects the extent to which companies can reliably repay debts, select three indicators such as net cash flow, cash flow debt ratio, asset-liability ratio. Growth ability selects three indicators: sales growth rate, net profit growth rate, and capital accumulation rate. As for the operational capacity of enterprises, this paper uses the current assets turnover rate and total asset turnover rate to measure.

\section{Indicator selection for measuring the external financing environment}

By studying the existing literature, it is noticed that the research on the external environment of patent financing is mostly focused on the construction of financing service platform, the choice of financing business model, and the preferential policies on fiscal and taxation, etc. The study of external financing environment has only a few categories and specific measurement indicators. Li Xiaolin studied the impact of innovation environment on enterprise innovation capability by using the Suzhou high-tech enterprise data. Among them, the innovation environment is divided into four dimensions: policy and legal environment, market environment, resource environment, technology and service environment, corresponding specific measurement indicators are proposed[22].

In recent years, with the vigorous promotion of Chinese government, the financing of intellectual property has been greatly improved, and the amount of financing is also increasing every year. In order to determine the indicators for measuring external financing environment, this paper selects the most influential government subsidy policy as the first-level indicator, focusing on the impact of the government's economic subsidy policy. Specifically, starting from the specific projects for enterprises to enjoy economic subsidies, funding for science and technology activities, enjoy high-tech corporate income tax relief, $\mathrm{R} \& \mathrm{D}$ plus tax deduction, technology transfer income tax relief are used. Finally, we get the evaluation index system for patent financing capability as shown in TABLE I.

TABLE I. EVALUATION INDEX SYSTEM FOR PATENT FINANCING CAPABILITY

\begin{tabular}{|c|c|c|}
\hline Dimensions & Primary indicators & Secondary indicators \\
\hline \multirow{3}{*}{ Patent value } & Patented technical features & $\begin{array}{l}\text { Number of valid invention patents } \\
\text { Family patent number } \\
\text { Patent maintenance period }\end{array}$ \\
\hline & Patented Market features & $\begin{array}{l}\text { Patented technology market demand } \\
\text { Patented technology alternative } \\
\text { Patent product market competition } \\
\text { Remaining economic life }\end{array}$ \\
\hline & Patent Law Features & $\begin{array}{l}\text { Patent remaining validity period } \\
\text { Patent license implementation quantity } \\
\text { Number of patent infringement lawsuits } \\
\text { Number of patent invalidation proceedings }\end{array}$ \\
\hline
\end{tabular}




\begin{tabular}{|c|c|c|}
\hline \multicolumn{3}{|c|}{ Cont. to TABLE I } \\
\hline \multirow{5}{*}{ Business status } & Business scale & Totalass et logarithm \\
\hline & Profitability & $\begin{array}{l}\text { Sales Net Profit } \\
\text { Sales gross margin } \\
\text { Return on equity }\end{array}$ \\
\hline & Repayment ability & $\begin{array}{l}\text { Net cash flow } \\
\text { Cash flow debt ratio } \\
\text { Asset-liability ratio }\end{array}$ \\
\hline & Growth ability & $\begin{array}{l}\text { Sales growth rate } \\
\text { Net profit growth rate } \\
\text { Capital accumulation rate }\end{array}$ \\
\hline & Operational capacity & $\begin{array}{l}\text { Current asset turnover } \\
\text { Total asset turnover }\end{array}$ \\
\hline External financing environment & Government subsidy policy & $\begin{array}{l}\text { Funding for science and technology activities } \\
\text { Enjoy high-tech corporate income taxrelief } \\
\text { R\&D plus tax deduction } \\
\text { Technology transfer income taxrelief }\end{array}$ \\
\hline
\end{tabular}

\section{CONCLUSION}

The amount of patenting and granted has growing rapidly these recent years, but the rate of patent conversion did not show synchronous growth. Realization of innovation performance in high-tech enterprises is often constrained by shortage of funds, in such a situation, financing via patent can be an effective way to solve this problem. This paper analyzed the impacts of patent financing capacity from three dimensions by patent value, business status and external financing environment, and constructed a set of evaluation index system for patent financing capacity. The system will help measure the company's financing capacity from the perspective of patents, reveal the key elements of enhancing patent financing capacity, and promote the formation of patent-based financing decision. Subsequent research will collect data by way of field surveys and questionnaire surveys of sample companies in order to improve and optimize the proposed evaluation index system. Through practical measurement, verification of the rationality and validity of the indicators, practicality and operability of the recommendations derived from this article will be enhanced.

\section{REFERENCES}

[1] Cheng Mei. Research on the Legal Issues of Intellectual Property Right for Industrialization of Enterprises' Patents. Shanghai: Shanghai University, 2015. (In Chinese)

[2] Pu Jiang. Research on the Financing of High-tech Enterprises. Chengdu: Southwest University of Finance and Economics, 2001. (In Chinese)

[3] Liu Shuxian. The Influence of Corporate Financing Channel Selection on Independent Innovation Capability. Kunming: Yunnan University of Finance and Economics, 2011. (In Chinese)

[4] Yao Wangxin, Zhang Xiaoyan. "Evaluation of intellectual property financing capacity based on analysis”. Science Technology Progress and Policy, vol. 29, pp. 107-112, 2012. (In Chinese)

[5] Xue Zhili. Research on Influencing Factors of Intellectual Property Financing. Hohhot: Inner Mongolia University, 2012. (In Chinese)

[6] Niu Caoling, Xue Zhili. "Research on intellectual property (IP) financing constraints”. Communication of Finance and Accounting, vol. 24, pp. 114-119, 2013. (In Chinese)

[7] Zhu Sha. Research on Patent Pledge Financing for China's Science and Technology Medium and Small Enterprises. Changsha: Changsha University of Science and Technology,2015. (In Chinese)
[8] Zhang Hongfang. "Preliminary study on the establishment of the index system of patented enterprises for patent right pledge". Studies in Science of Science,vol. 35, pp. 1026-1031, 2017. (In Chinese)

[9] Hua Hefeng, Bao Yanli. "The construction of evaluation index system of intellectual property financing ability for s mall and micro enterprises in science and technology”. Finance and Accounting Monthly, vol. 21, pp. 71-75, 2016. (In Chinese)

[10] Huang Qing, Cao Jinyan, Yu Weijun. "Patent evaluation index system (1) - design and construction of patent evaluation index system". Intellectual Property, vol. 5, pp. 25-28, 2004. (In Chinese)

[11] Wan Xiaoli, Zhu Xuezhong. "Evaluation index system and fuzzy comprehensive evaluation of patent value". Science Research Management, vol. 2, pp. 185-191, 2008. (In Chinese)

[12] Liu Shuai. Study on the Evaluation Index System of Patent Value for Industry. Zhenjiang: Jiangsu University, 2016. (In Chinese)

[13] Lv Xiaorong. "Empirical research on evaluation index system of patent value and evaluation of patented technology quality". Science Technology Progress and Policy, vol. 31, pp. 113-116, 2014. (In Chinese)

[14] Hu Hui, Wang Yuandi. "Research on the composite index of patent quality of enterprises: taking the listed company of GEM as an Example”. Journal of Information, vol. 34, pp. 77-82, 2015. (In Chinese)

[15] Zhang Xiaoyue, Chen Penglong, Zhao Weiyi. "Study on the relationship between patent quality and corporate performance: taking the listed companies on the GEM as an example”. Science and Technology Management Research, vol. 22, pp. 170-176, 2017. (In Chinese)

[16] Xu Wei. Research on the Financing Ability Index System of Science and Technology SMEs. Wuxi: Jiangnan University, 2012. (In Chinese)

[17] Wu Yulin, Sun Wenbo. "Analysis of factors influencing financing capacity of high-tech firms: an empirical study based on a classified regression tree model”. Management Modernization, vol. 36, pp. 5-7, 2016. (In Chinese)

[18] Zhang Haohao. Research on the Influencing Factors of Financing Capacity of China's GEM Listed Companies. Shandong University, 2014. (In Chinese)

[19] Xu Shiying, Zhang Qing, Li Jiao. “Analysis of operational capability of strategic emerging industries: taking listed companies in Sichuan and Shanghai as examples”. Friends of Accounting, vol. 10, pp. 44-48, 2016. (In Chinese)

[20] Xu Zhengsheng. Analysis of Financial Statements, 3rd ed. Beijing: Tsinghua University and Beijing Jiaotong University, 2012. (In Chinese)

[21] Erich.A. Helfert. Techniques of Financial Analysis. Liu Yilun, Zhu Xiaohui. Beijing: Posts \& Telecom Press, 2010. (In Chinese)

[22] Li Xiaolin. Research on the Influence of Innovation Environment on Enterprise's Innovation Ability. Suzhou: Soochow University, 2012. (In Chinese) 